\title{
PENGGUNAAN MEDIA GAMBAR PADA MATA PELAJARAN PENDIDIKAN AGAMA ISLAM MATERI SHALAT JENAZAH DI KELAS IX J SMP NEGERI 1 KUNINGAN KABUPATEN KUNINGAN
}

\author{
Oleh: \\ Masduki Hariyantoni \\ Guru SMP NEGERI 1 KUNINGAN \\ Email: Masdukihariyantoni@gmail.com
}

\begin{abstract}
ABSTRAK
Kurikulum Dua Ribu Tiga Belas telah mengubah tata cara pembelajaran yang ada di sekolah. Selama ini guru cenderung menggunakan model pengajaran dengan menggunakan gambar, guru memberikan informasi atau transfer ilmu dan siswa menerimanya. Model pembelajaran dengan menggunakan gambar yang identik dengan ceramah terbukti di dalam pelaksanaannya tidak berpengaruh besar kepada keberhasilan belajar siswa. Dengan penerapan KTSP maka tata cara pengajaran juga harus berubah, oleh karena itu diperlukan suasana pembelajaran yang menyenangkan, yang bisa menjadikan siswa aktif dan senang untuk belajar.

Tujuan yang ingin dicapai dalam penelitian ini adalah untuk mengetahui: 1) proses penerapan model pembelajaran dengan menggunakan gambar dalam upaya meningkatkan hasil belajar siswa dalam pembelajaran PAI di kelas IX J SMP Negeri 1 Kuningan Kabupaten Kuningan, dengan menggunakan metode kuantitatf dengan populasi sampel anak kelas IX J melalui observasi dan wawancara.

Dari analisis data penelitian diperoleh: Hasil belajar siswa dalam pembelajaran PAI melalui penerapan model pembelajaran dengan menggunakan gambar di kelas IX J SMP Negeri 1 Kuningan Kabupaten Kuningan mengalami peningkatan. Peningkatan hasil belajar siswa tersebut dibuktikan dengan perolehan nilai rata-rata kelas, di mana setiap perbaikan mengalami peningkatan yang sangat signifikan. Pra siklus hanya mencapai nilai rata-rata kelas sebesar 6,37, siklus I meningkat menjadi 7,33, dan siklus II memperoleh nilai rata-rata kelas sebesar 8,07.
\end{abstract}

Kata Kunci: Penggunaan, Media Gambar, Shalat Jenazah. 


\begin{abstract}
The Twelve-Thirteen Thousand curriculum has changed the procedures for learning in schools. So far, teachers tend to use teaching models using images, teachers provide information or transfer of knowledge and students receive it. The learning model by using images that are identical to the lecture proved that the implementation did not have a major effect on the success of student learning. With the application of KTSP, the teaching procedures must also change, therefore a pleasant learning atmosphere is needed, which can make students active and happy to learn.

The objectives to be achieved in this study are to find out: 1) the process of applying learning models using images in an effort to improve student learning outcomes in PAI learning in class IX J Kuningan 1 Kuningan Middle School, using a quantitative method with a sample population of class IX children $J$ through observation and interviews.

From the analysis of research data obtained: Student learning outcomes in PAI learning through the application of learning models using images in class IX J SMP Negeri 1 Kuningan Kuningan Regency has increased. Improving student learning outcomes is evidenced by the acquisition of class average values, where each improvement experienced a very significant increase. The pre cycle only reaches the class average value of 6.37 , the first cycle increases to 7.33 , and the second cycle gets the class average value of 8.07.
\end{abstract}

Keywords: Usage, Image Media, Prayer Prayer.

\title{
A. PENDAHULUAN
}

Pembangunan di bidang pendidikan sebagai salah satu bagian dari pembangunan Nasional, perlu diwujudkan guna peningkatan dan kemajuan sektor pendidikan. Merosotnya kualitas pendidikan banyak mendapat sorotan dari masyarakat, lulusan siswa, para pendidik, dan pemerintah. Oleh karena itu pemerintah berupaya semaksimal mungkin mengadakan perbaikan dan 
penyempurnaan di bidang pendidikan. Sebagai langkah antisipasi, maka pendidikan banyak diarahkan pada penataan proses belajar, penggunaan dan pemilihan media belajar secara tepat. Semuanya dimaksudkan untuk pencapaian hasil belajar semaksimal mungkin.

Dalam proses pendidikan Islam, metode memiliki kedudukan yang sangat signifikan untuk mencapai tujuan pendidikan Islam. Bahkan metode sebagai seni dalam mentransfer ilmu pengetahuan kepada siswa dianggap lebih signifikan dibanding dengan materi itu sendiri.

Dari hasil pembelajaran PAI yang dilakukan penulis di kelas IX J SMP Negeri 1 Kuningan Kabupaten Kuningan diketahui bahwa hasil belajar siswa pada mata pelajaran PAI tergolong menurun. Menurunnya hasil belajar siswa pada mata pelajaran PAI diindikasikan sebagai berikut: 1) Metode pembelajaran yang digunakan kurang menarik perhatian siswa; 2) Guru kurang melibatkan siswa secara aktif dalam proses pembelajaran; 3) Guru tidak memanfaatkan lingkungan sebagai sumber alat peraga; 4) pengelolaan kelas dalam pembelajaran kurang maksimal; 5) pengorganisasian kelompok belajar kurang maksimal; 6) Siswa kurang antusias dalam mengikuti pembelajaran; dan 8) Siswa kurang memahami materi pelajaran.

Alternatif tindakan yang dapat dilakukan penulis untuk memecahkan permasalahan yang telah teridentifikasi di atas yaitu dengan menerapkan atau mengimplementasikan model pembelajaran dengan menggunakan gambar., Adapun prioritas pemecahan masalahnya adalah ditujukan pada peningkatan hasil belajar PAI siswa.

Metode kerja kelompok sering dianggap kurang efektif, berbagai sikap dan kesan negatif memang bermunculan dalam pelaksaan metode kerja kelompok. Jika kerja kelompok tidak berhasil, siswa cenderung saling menyalahkan. Sebaliknya jika berhasil, muncul perasaan tidak adil. Siswa yang pandai/rajin merasa rekannya yang kurang mampu telah membonceng pada hasil kerja mereka. Akibatnya, metode kerja kelompok yang seharusnya bertujuan mulia, yakni menanamkan rasa persaudaraan dan kemampuan bekerja 
sama, justru bisa berakhir dengan ketidakpuasaan dan kekecewaaan. Bukan hanya guru dan siswa yang merasa pesimis mengenai penggunaan metode kerja kelompok, bahkan kadang-kadang orang tua pun merasa was-was jika anak mereka dimasukkan dalam satu kelompok dengan siswa lain yang dianggap kurang seimbang, sehingga timbul permasalahan;

a. Bagaimana penggunaan media gambar pada pokok bahasan Tata Cara Pengurusan Jenazah di Kelas IX J SMP Negeri 1 Kuningan?

b. Bagaimana aktivitas siswa dalam pembelajaran pendidikan Agama Islam di Kelas IX J SMP Negeri 1 Kuningan?

c. Bagaimana prestasi yang dicapai oleh siswa pada mata pelajaran Pendidikan Agama Islam dengan menggunakan media gambar?

\section{B. LANDASAN TEORI}

1. Media Pembelajaran Melalui Gambar

Media gambar merupakan penyajian dua visual yang memanfaatkan rancangan gambar sebagai arana pertimbangan mengenai kehidupan sehari-hari, misalnya yang menyangkut manusia, peristiwa, benda-benda, tempat, dan sebagainya. Pendapat lain menerangkan bahwa media gambar adalah media yang mengkombinasi fakta dan gagasan secara jelas dan kuat melalui kombinasi pengungkapan kata-kata dengan gambar. ${ }^{1}$

2. Pendidikan Agama Islam

Pengertian pendidikan itu bermacam-macam, hal ini disebabkan karena perbedaan falsafah hidup yang dianut dan sudut pandang yang memberikan rumusan tentang pendidikan itu. Pendidikan adalah usaha sadar yang dengan sengaja dirancangkan untuk mencapai tujuan yang telah ditetapkan. Sedangkan Ihsan mengatakan bahwa pendidikan merupakan usaha manusia untuk menumbuhkan dan mengembangkan potensi-potensi pembawaan baik jasmani maupun rohani sesuai dengan nilai-nilai yang ada di dalam masyarakat dan kebudayaan. Atau dengan kata lain bahwa pendidikan dapat

\footnotetext{
${ }^{1}$ Nana Sudjana, Penelitian dan Penilaian Pendidikan (Bandung, Sinar Baru, 2011), 68. 
diartikan sebagai suatu hasil peradaban bangsa yang dikembangkan atas dasar pandangan hidup bangsa itu sendiri (nilai dan norma masyarakat) yang berfungsi sebagai filsafat pendidikannya atau sebagai cita-cita dan pernyataan tujuan pendidikannya. Sedangkan Pendidikan Agama Islam adalah usahausaha secara sistematis dan pragmatis dalam membantu anak didik agar mereka hidup sesuai dengan ajaran Islam. ${ }^{2}$

\section{METODOLOGI}

Metode yang digunakan peneliti dalam penelitian ini adalah dengan menggunakan Penelitian Tindakan Kelas Model Kemmis dan Mc. Taggart.

Beberapa ahli telah mengemukakan tentang penelitian tindakan kelas (PTK), di antaranya adalah Ebbut yang menjelaskan bahwa "Penelitian tindakan kelas adalah kajian sistematik dari upaya perbaikan pelaksanaan praktek pendidikan oleh sekelompok guru dengan melakukan tindakan-tindakan tersebut". ${ }^{3}$ Dengan demikian setiap siklus yang dilakukan berdasarkan model spiral dari Kemmis dan Taggart ini dimulai dari tahap perencanaan, pelaksanaan, tindakan, observasi dan refleksi kemudian mengadakan perencanaan kembali seperti yang dapat dilihat pada gambar berikut ini: Gambar Model Spiral Kemmis \& Taggart ${ }^{4}$

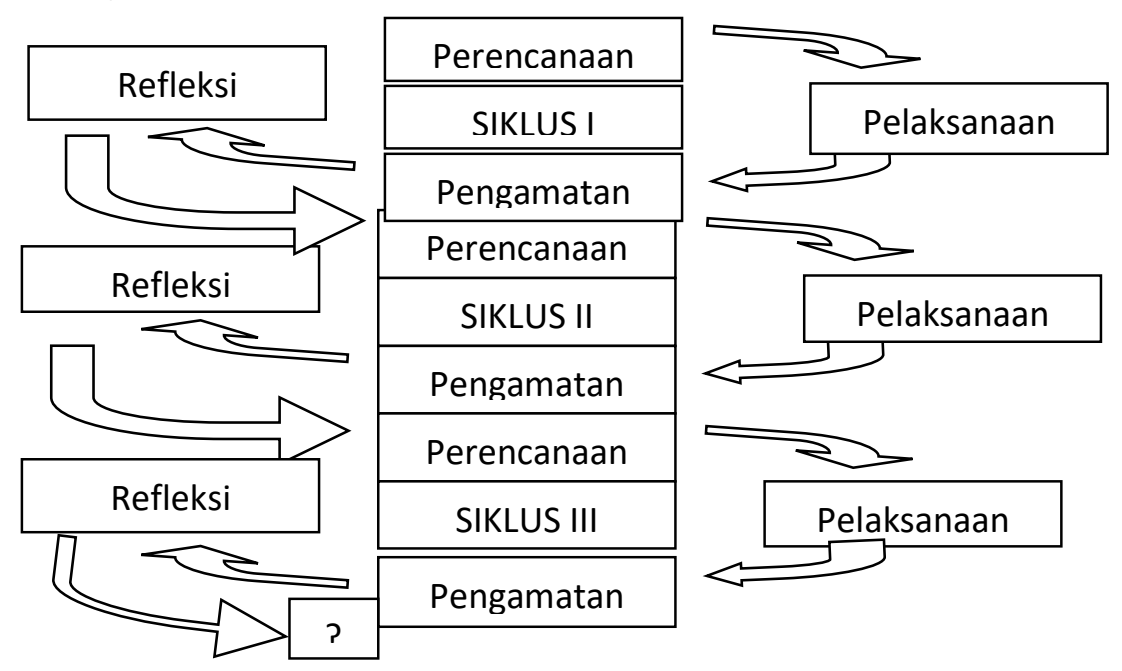

${ }^{2}$ Zuhaerini, Metodik Khusus Pendidikan Agama (Surabaya : Usaha Nasional, 1983), 27.

${ }^{3}$ Wiriatmadja Rochiati, Metode Penelitian Tindakan Kelas (Bandung: PT Remaja Rosdakarya, 2005), 12.

${ }^{4}$ Wiriatmadja Rochiati, Metode Penelitian Tindakan Kelas, 66. 
Penelitian tindakan kelas adalah "bagaimana sekelompok guru dalam mengorganisasikan kondisi praktik pembelajaran dan belajar dari pengalaman mereka sendiri sehingga dapat mencobakan suatu gagasan perbaikan praktik pembelajaran tersebut".5 Sedangkan Suhardjono mengemukakan penelitian tindakan kelas adalah "penelitian tindakan yang dilakukan dengan tujuan memperbaiki mutu praktek pembelajaran dikelasnya". 6

Desain penelitian yang digunakan adalah berbentuk siklus yang mengacu kepada rancangan penelitian yang dilakukan oleh Kemmis dan Taggart yaitu model spiral. Dalam model spiral ini digunakan empat komponen penelitian tindakan (perancanaan, tindakan, observasi dan refleksi) dalam suatu sistem spiral yang saling terkait.

Penelitian tindakan kelas ini dilaksanakan di kelas IX J SMP Negeri 1 Kuningan Kabupaten Kuningan yang berjumlah 40 siswa, yang terdiri atas 21 siswa perempuan dan 19 siswa laki-laki. Mata pelajaran yang dilaksanakan dalam subyek penelitian ini adalah PAI.

\section{PEMBAHASAN}

1. Pengertian Belajar

Karena belajar merupakan permasalahan setiap orang, tidak mustahil banyak pihak yang berusaha mempelajari dan menerangkan tentang hakikat belajar tersebut. Hingga sekarang para ahli ilmu jiwalah yang paling berhasil memberikan sumbangan dalam menjawab banyak persoalan mengenai belajar.

Yang disebut belajar itu adalah suatu perubahan dalam pelaksanaan tugas yang terjadi sebagai hasil dari pengamalan yang tidak ada hubungannya dengan kematangan rohaniah, kelelahan, motivasi, perubahan

\footnotetext{
${ }^{5}$ Wiriatmadja Rochiati, Metode Penelitian Tindakan Kelas, .............., 12.

${ }^{6}$ Suharsimi Arikunto, Prosedur Penelitian Suatu Pendekatan Praktik (Jakarta: Rineka Cipta, 2006), 58. 
dalam situasi rangsangan atau faktor-faktor lainnya yang tidak ada hubungannya dengan kegiatan belajar. ${ }^{7}$

Selain itu definisi belajar banyak pula orang yang menerangkan bahwa belajar adalah suatu pembentukan hubungan-hubungan tertentu dalam system urat saraf sebagai hasil respon terhadap stimulus. Dengan kata lain masalah belajar dianggap sebagai perubahan fisiologis, yang tidak dapat dibuktikan kebenarannya dan terjadi pada masalah suatu bagian dari organisme yakni dalam system urat saraf.

Belajar adalah proses melahirkan atau mengubah sesuatu kegiatan melalui jalan latihan (apakah dalam labolatorium atau dalam lingkungan amaliah) yang dibedakan dari perubahan oleh faktor-faktor yang tidak termasuk latihan. ${ }^{8}$

2. Jenis-jenis Belajar

Belajar dapat dibedakan kedalam beberapa jenis, antara lain:

a. Belajar berdasarkan pengamatan (Sensory type of learning);

b. Belajar berdasarkan gerak (Motor type of learning);

c. Belajar berdasarkan hapalan (Memory of learning);

d. Belajar berdasarkan pemecahan masalah (Problem type of learning);

e. Belajar berdasarkan emosi (Imotional type of learning). ${ }^{9}$

3. Prestasi Belajar

Setelah mengalami proses belajar mengajar, siswa akan mengalami perubahan tingkah laku yang bersifat pengetahuan (Kognitif), keterampilan (Psikomotor), atau yang menyangkut nilai dan sikap (Afektif). ${ }^{10}$

Prestasi belajar yang dicapai siswa pada umumnya ditunjukkan oleh angka atau huruf yang dituangkan dalam buku raport. Buku raport berisi laporan tentang prestasi belajar siswa sebagai hasil belajarnya secara khusus kepada orangtua atau wali siswa.

\footnotetext{
${ }^{7}$ Melvin sulberman, Active Learning 101 Cara Belajar Siswa Aktif (Bandung: Nuansa, 2006), 172.

${ }^{8}$ S. Nasution, Berbagi Pendekatan dalam Proses Belajar Mengajar (Jakarta: Bumi Aksara, 2006), 46.

${ }^{9}$ Moh. Ali, Guru dalam Proses Belajar Mengajar (Bandung. Sinar Bari, 2007), 43.

${ }^{10}$ Abdul Halim (ed), Metodologi Pengajaran Agama Islam (Jakarta: Ciputat Press, 2002), 1-6. 
Perubahan perilaku siswa yang diharapkan sebagai hasil belajar yang telah dilaluinya mengindikasikan bahwa proses belajar mengajar mencapai kategori berhasil, kurang berhasil, atau gagal.

Ajaran Islam mengindikasikan adanya perolehan prestasi belajar yang dapat dicapai oleh orang yang belajar. Artinya usaha-usaha yang dilakukan peserta belajar pada akhirnya akan mencapai keberhasilan dari proses belajar yang dialaminya. Firman Allah dalam Surat Al-Ankabut ayat 20, Artinya: "Katakanlah: Berjalanlah kamu sekalian di atas bumi ini, maka kamu lihatlah bagaimana mulainya timbul kejadian."11

4. Faktor-faktor yang Mempengaruhi Pretasi Belajar

Secara garis besar ada dua faktor yang mempengaruhi prestasi belajar yaitu faktor pembawaan dan faktor lingkungan. Suatu pembawaan tidak dapat mencapai perkembangannya jika tidak dipengaruhi oleh lingkungan. Lebih tegas dijelaskan bahwa perkembangan manusia ditentukan atau merupakan hasil dua faktor adalah pembawaan dan lingkungan. ${ }^{12}$

Faktor pembawaan atau internal dapat berupa bawaan seseorang seperti intelijensi yang memiliki kemampuan yang dibawa sejak lahir, yang memungkinkan seseorang berbuat sesuatu dengan cara tertentu. ${ }^{13}$ Sedangkan faktor lingkungan atau eksternal terdiri dari faktor lingkungan keluarga, sekolah, dan masyarakat. Lingkungan keluarga dapat menentukan terhadap prestasi belajar. Sebagaimana dijelaskan bahwa suasana dan keadaan keluarga yang bermacam-macam itu mau tidak mau turut menentukan bagaimana dan sampai di mana belajar dialami dan dicapai oleh anak-anak. Termasuk dalam keluarga ini, ada tidaknya atau tersedianya fasilitas-fasilitas yang diperlukan dalam belajar turut memegang peranan penting pula. ${ }^{14}$

Lingkungan sekolah banyak berpengaruh karena ketika siswa hadir di sekolah ditemui berbagai macam keadaan siswa, ada yang rajin belajar ada

\footnotetext{
${ }^{11}$ Habi Ashshidiqie dkk., Al-Quran dan Terjemahannya (Jakarta: Kemenag RI, 2010), 631.

${ }^{12}$ Ngalim Purwanto, Administrasi dan Supervisi Pendidikan (Bandung: Remaja Rosda Karya, 2008), 17.

${ }^{13}$ Ngalim Purwanto, Administrasi dan Supervisi Pendidikan

${ }^{14}$ Ngalim Purwanto, Administrasi dan Supervisi Pendidikan, ... 59. 109. 
yang kurang rajin belajar. Hal tersebut akan membawa dampak baik atau buruk pada kedua belah pihak. Dalam lingkungan masyarakat, siswa merupakan salah satu anggota masyarakat yang mau tidak mau akan bertemu dengan keadaan siswa dimasyarakat, baik yang sekolah atau teman yang tidak sekolah. Ketiga faktor lingkungan terebut di ata sangat dominan dalam menentukan maju mundurnya prestasi belajar siswa termasuk prestasi belajar mata pelajaran PAI yang merupakan mata pelajaran wajib diterapkan di lembaga pendidikan sekolah, karena Pendidikan Agama Islam memiliki karakteristik sebagai berikut:

a. PAI merupakan mata pelajaran yang dikembangkan dari ajaran dasar/pokok yang terdapat dalam agama Islam;

b. PAI merupakan mata pelajaran yang menjadi komponen yang tidak dapat dipisahkan dengan mata pelajaran lain dengan memiliki tujuan untuk pengembangan moral dan kepribadian peserta didik;

c. PAI memiliki tujuan untuk terbentuknya peserta didik yang beriman dan bertakwa kepada Allah Subhanahu Wata'ala, berbudi pekerti luhur, dan memiliki pengetahuan yang cukup tentang Islam.

d. PAI lebih menekankan bagaimana peserta didik mampu menguasai pengamalan dalam kehidupan sehari-hari dari kajian Islam yang dipelajarinya;

e. PAI didasarkan pada ketentuan sumber pokok ajaran Islam, yaitu al-Quran dan Hadits;

f. Prinsip PAI memiliki tiga kerangka dasar, yaitu akidah, syariah, dan akhlak;

PAI merupakan mata pelajaran wajib yang harus diikuti oleh setiap peserta didik, terutama yang beragama Islam

Untuk memudahkan dalam pembelajaran diperlukan media yang dapat mempermudah anak dalam memahami materi, salah satunya dengan media gambar yang fungsinya untuk melukiskan beraneka ragam gagasan, misalnya gambar Pangeran Diponegoro yang sedang menunggang kuda dengan kepala bersorban, memberi kesan gagahnya beliau sebagai Pahlawan Islam berjuang 
menentang penjajah, serangkaian potret haji memperlihatkan betapa tahapantahapan ibadah haji itu dijalani dan dilaksanakan. ${ }^{15}$

Dalam penggunaan media gambar dalam pembelajaran, ada beberapa hal yang harus diketahui, antara lain:

a. Yang perlu diperhatikan:

1. Gambar yang bagus, menarik, jelas, dan mudah dimengerti;

2. Gambar harus cocok dan cukup penting sesuai dengan hal yang sedang dipelajari;

3. Gambar memiliki kesederhanaan dan tidak rumit, sehingga mudah dipahami siswa;

4. Gambar harus sesuai dengan kecerdasan orang yang melihatnya;

5. Ukuran gambar sesuai dengan kebutuhan.

b. Prinsip Umum Penggunaan Media Gambar

1. Gambar realistis dan digunakan secara hati-hati;

2. Gambar berfungsi untuk melukiskan perbedaan konsep;

3. Warna gambar digunakan untuk mengarahkan perhatian dan membedakan komponen-komponen.

c. Kelebihan Media Gambar

1. Gambar sifatnya konkret;

2. Gambar dapat mengatasi batasan ruang dan waktu;

3. Media gambar dapat mengatasi keterbatasan pengamatan kita;

4. Media gambar dapat memperjelas suatu masalah;

5. Media gambar murah dan tanpa memerlukan peralatan khusus.

d. Kelemahan Media Gambar

1. Gambar hanya menekankan persepsi indera mata;

2. Gambar benda yang terlalu kompleks kurang efektif untuk kegiatan belajar;

3. Ukuran sangat terbatas, tidak memadai untuk kelompok besar.

e. Petunjuk Menggunakan Media Gambar

${ }^{15}$ Zakiah Drajat, Kepribadian Guru (Jakarta, Bulan Bintang, 2005), 199.

Jurnal Pendidikan Agama Islam

IAIN Syekh Nurjati Cirebon 
1. Kurangi beban verbal, terutama yang lambat menangkap bacaan;

2. Dapat mengungkapkan hal-hal istimewa;

3. Memperhatikan kontras, komparasi, dan kontinuitas;

4. Merangsang ekspresi kreatif, artinya melahirkan/mencurahkan perasaan dan pikiran yang dinyatakan melalui bentuk ciptaan baru;

5. Menilai kemajuan siswa, yaitu dapat meningkatkan dan mendayagunakan media pendidikan, termasuk dalam penilaian. ${ }^{16}$

Dari penjelasan teori di atas, maka untuk mengetahui proses penerapan model pembelajaran dengan menggunakan gambar dalam upaya meningkatkan hasil belajar siswa dalam pembelajaran PAI di kelas IX J SMP Negeri 1 Kuningan Kabupaten Kuningan. Selain itu untuk mengetahui hasil belajar siswa dalam pembelajaran PAI melalui penerapan model Pembelajaran dengan menggunakan gambar Pada Siswa Kelas IX J SMP Negeri 1 Kuningan Kabupaten Kuningan.. Hasil penelitian tersebut dideskripsikan sebagai berikut:

Tabel 4.9 Tentang Hasil Per Siklus

Tahap Rata-rata Prosentase Jumlah siswa tuntas, Jumlah siswa tidak tuntas. Siklus I: 45\%, 55\%. Siklus II: 60\%, 40\%. Dari tabel 4.9 bisa dilihat deskripsi dari masing-masing siklus adalah sebagai berikut : 1 . Siklus I dengan rata- rata 7,33; 2. Siklus II dengan rata-rata 8,07.

Melalui hasil peneilitian ini menunjukkan bahwa metode pembelajaran penerapan model pembelajaran dengan menggunakan gambar dalam meningkatkan prestasi belajar siswa. Hal ini dapat dilihat dari tabel berikut: Perbandingan nilai rata-rata kelas hasil belajar penerapan metode pembelajaran interaktif dalam meningkatkan pengetahuan siswa kelas IX J SMP Negeri 1 Kuningan, pada Siklus I dan Siklus II metode pembelajaran penerapan model kooperatif tipe TPS di kelas IX J SMP Negeri 1 Kuningan memiliki dampak positif dalam meningkatkan prestasi belajar siswa. Hal ini dapat dilihat dari semakin mantapnya pemahaman siswa terhadap materi yang disampaikan guru

${ }^{16}$ Zakiah Drajat, Kepribadian Guru, 202-206 
(ketuntasan belajar meningkat dari Pra sklus, I dan II) . Pada siklus II ketuntasan belajar siswa telah tercapai.

Selanjutnya untuk memperkuat pembahaan, setelah data terkumpul melalui studi dokumentasi kemudian diklasifikasikan dan mencoba untuk dianalisis, langkah selanjutnya juga dijelaskan penerapan penggunaan media gambar sebelum diterapkannya penggunaan media gambar pada mata pelajaran Pendidikan Agama Islam denan materi Tata Cara Penguruan Jenazah, ternyata dengan media gambar yang dilakukan oleh lebih mengena dan lebih dipahami oleh siswa baik dalam prilaku di sekolah maupun praktek dalam kehidupan sehari-hari.

Dengan demikian kesimpulan penelitian dapat dilihat dari hasil nilai rata-rata yang diperoleh siswa sebelum, selama, dan perbaikan dengan menggunakan media gambar , menunjukkan baha nilai rata-rata adalah:

1. Belum diterapkan penggunaan media gambar nilai rata-rata 6,37 ;

2. Setelah digunakan media gambar dan diskusi nilai rata-rata 7,33;

3. Setelah diadakan perbaikan dengan penggunaan media gambar nilai rata-rata 8,07 .

Dengan gambaran terebut di atas, dapat dinyatakan bahwa penggunaan media gambar lebih tepat dalam pembelajaran Pendidikan Agama Islam pada materi Tata Cara Pengurusan Jenazah, sehingga menunjukkan hasil pembelajaran tergolong baik.

\section{E. KESIMPULAN}

1. Proses pembelajaran dengan menggunakan gambar dalam upaya meningkatkan hasil belajar siswa dalam pembelajaran PAI kelas IX J SMP Negeri 1 Kuningan Kabupaten Kuningan dilakukan secara sistematis, hal ini melalui tahapan pembelajaran sesuai dengan langkah-langkah pembelajaran dalam RPP. Dalam proses pembelajaran ini lebih menekankan pada pembelajaran kooperatif model TPS.

2. Hasil belajar siswa dalam pembelajaran PAI melalui penerapan pembelajaran dengan menggunakan gambar di kelas IX J SMP Negeri 1 Kuningan Kabupaten 
Kuningan mengalami peningkatan, peningkatan hasil belajar siswa tersebut dibuktikan dengan perolehan nilai rata-rata kelas, dimana setiap perbaikan mengalami peningkatan yang sangat drastis. Pra siklus hanya mencapai nilai rata-rata kelas sebesar 6,37, siklus I meningkat menjadi 7,33, dan siklus II memperoleh nilai rata-rata kelas sebesar 8,07.

\section{DAFTAR PUSTAKA}

Ali, Moh, (2007). Guru dalam Proses Belajar Mengajar. Bandung: Sinar Baru.

Arikunto, Suharsimi. (2006). Prosedur Penelitian Suatu Pendekatan Praktik. Jakarta: Rineka Cipta.

Ashshidiqie, Habi, dkk. (2010). Al-Quran dan Terjemahannya.Jakarta. Kemenag RI.

Drajat, Zakiah, (2005). Kepribadian Guru. Jakarta, Bulan Bintang.

Halim, Abdul, (ed), Metodologi Pengajaran Agama Islam (Jakarta: Ciputat Press, 2002).

Sudjana, Nana, (2011). Penelitian dan Penilaian Pendidikan. Bandung, Sinar Baru.

Nasution, S., (2006). Berbagi Pendekatan dalam Proses Belajar Mengajar (Jakarta: Bumi Aksara.

Sulberman, Melvin, ( 2006). Active Learning 101 Cara Belajar Siswa Aktif. Bandung: Nuansa.

Purwanto, Ngalim, (2008). Administrasi dan Supervisi Pendidikan. Bandung: Remaja Rosda Karya.

Wiriatmadja, Rochiati. (2005). Metode Penelitian Tindakan Kelas. Bandung. PT Remaja Rosdakarya.

Zuhaerini, (1983). Metodik Khusus Pendidikan Agama. Surabaya : Usaha Nasional. 